\title{
Creating New Learning Environment to Foster Enrollment in Engineering Programs
}

\author{
Claudio da Rocha Brito \\ Science and Education Research Council \\ São Paulo, Brazil \\ dr brito @c opec.eu \\ Melany M. Ciampi \\ World Council on Systems Engineering and Technology Information \\ São Paulo, Brazil \\ drciampi @c opec.eu \\ Luis Amaral \\ Computer Graphics Center \\ Guimarães, Portugal \\ a mar al @dsi.umi nho.pt \\ Rosa Vasconcelos \\ University of Minho \\ Guimarães, Portugal \\ rosa@det.uminho.pt \\ Victor F. A. Barros \\ Science and Education Research Council \\ Braga, Portugal \\ vi ctor@e opec.eu
}

\begin{abstract}
A discovery adventure! This is the program that has been developed by the Education Research Team of COPEC - Science and Education Research Council - a K12 School program for a city, with the goal of providing better and effective knowledge for young students, especially those who do not think about to enter a University. The main goal is to encourage more bright young minds to pursue careers in engineering or technology, by providing K12 students, from public schools of a municipality, knowledge about science and research methodology in a way that it will remain as a life practice. It fits into the counties' necessity to improve competitiveness in technology growth, which has implications in workforce development, as well as in science and technology development. The main characteristic of this project is the possibility to apply new and innovative approaches, which provide teenagers students the ability to develop concepts and theories to solve and understand
\end{abstract}

adfa, p. 1, 2011

(C) Springer-Verlag Berlin Heidelberg 2011

19th International Conference on Interactive Collaborative Learning (ICL2016) 21-23 September 2016, Clayton Hotel, Belfast, UK

Page 467 
scientific and nonscientific problems and, consequently, find solutions for those problems.

Keywords: K12, innovation, science, stem education, university access.

\section{Introduction}

Despite the differences among cultures and peoples fortunately education is currently seen as the most desirable path principally for young people to earn a decent living and to reach personal growth and happiness. It is generally agreed that educated people not only get higher incomes but also contribute considerably to business innovation, productivity and national economic development. Recent evidence also indicates that educated people can make decisions that help to get healthier and longer lives. So, it is possible to say that education can help to get success, health and happiness. This is the desire of all human beings and no doubt that education is a great part to foster human welfare. Education has also a strong and direct relationship between investment in education, educational achievement and economic growth.

These facts show that it is necessary to work on improving the quality of basic education or K12, mainly concerning basic knowledge in literacy, numeracy and the development of the essential life skills. However, it is necessary to deliver a highquality education with comparatively low spending. Therefore, public education, which should provide equal education access for all citizens, has to find ways to do so.

\section{Current K12 Education Status}

It is important to point out the importance of $\mathrm{K} 12$ education at present, since professional practices have changed tremendously and the requirements are not only very different from the previous professional generation, but they also keep changing, and quickly. It is imperative to develop means and ways to provide good quality K12 education, no matter what the economic level of the country is.

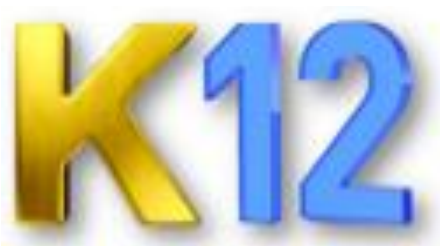

Fig. 1. K12.

Although challenging, many countries are making efforts to change to a K12 system worldwide. Governments are seeking for new ways to enhance the quality of basic education and, in many places, a massive amount of financial resources are addressed to this. However, financial resources will not be enough if there is no actual project, which contributes to the improvement of the educational system in order to assure 
children's future, the development of advanced learning systems and the improvement of the country's academic curriculum.

One good aspect about the K12 system is that there is a spiral progression, this means that the simplest topics will be discussed initially, and will later on progress to more advanced or complex topics, helping students to cope up with all their subjects. In the future, there might be a better system, to provide better education, however, at the current time $\mathrm{K} 12$ is the one [1].

\section{STEM Education}

STEM stands for science, technology, engineering and math, and these are the skills that countries need now and in the future. However they are not always emphasized as well as they could by schools. These disciplines are widely considered to be the 'underpinnings' of innovation capacity.

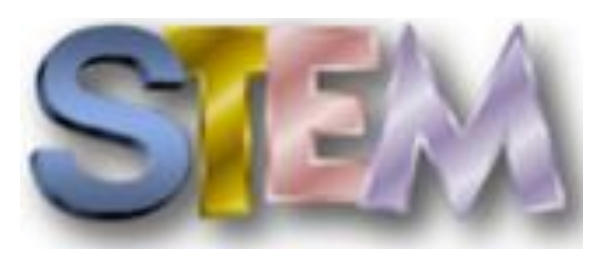

Fig. 2. STEM.

Apart from the discussions about the efficiency of STEM proposal, it is a way to overcome some gaps in education in order to enhance interest in technological professions, so necessary for the future of our society. What separates it from the traditional science and math education is the blended learning environment and showing students how the scientific method can be applied to everyday life. It teaches students computational thinking and focuses on the real world applications of problem solving. As mentioned before, STEM education begins while students are very young. It has long been argued, based on income data, that university completion is the mo st relevant indicator of a countries' ability to produce highly talented, innovative people. Many studies show that the choice of the discipline matters to outcomes as well. Some researches show, for example, that people with university degrees in academic disciplines - such as the humanities, education, biology, and agriculture scienceearn less than half of that earned by those with university degrees in vocational and applied disciplines - such as medicine, and engineering.

For every job advertisement for a bachelor's degree recipient in a non-STEM field there were 2.5 entry-level job advertisements for a bachelor's degree recipient in a STEM field.

What separates it from the traditional science and math education is the blended learning environment and showing students how the scientific method can be applied to everyday life. It teaches students computational thinking and focuses on the real world applications of problem solving [2]. 


\section{$4 \quad$ Brazilian Education System}

The Federal Constitution and the National Education Law determine the education system in Brazil. It is managed and organized separately by the various levels of the government and public administration:

- the federal government;

- the states;

- the federal district; and

- the municipalities.

Each of these levels is responsible for the educational sustainability, funding management and resource distribution.

The new constitution assigns $25 \%$ of the state budget and $18 \%$ of federal and municipal taxes to education [3].

Brazilian education is regulated by the federal government through the Ministry of Education, which defines the orienting principles of the organization of educational programs. The local governments are responsible for the establishment of state educational programs and follow the federal education guidelines, using funding provided by the federal government. Since 2006, mandatory schooling requires nine years (it was eight before), having as a key objective keeping the children at school for as long as possible, but, above all, to improve the quality of the in itial training and literacy.

However education in Brazil is still a consigned right for everyone by the Constitution of 1988, which establishes that 'education is a right for all, a duty of the state and the families, and is to be promoted with the collaboration of society with the objective to develop citizenship and the participation of citizens in the workforce, working towards social benefits that all can benefit from.' [4].

No matter the problems of the country, it is clear that education is somehow understood as a mean to guarantee a fairer society in one of the most unequal societies in the world.

\section{STEM in the Country}

The number of careers in Science, Technology, Eng ineering and Mathematics STEM is on the rise. These jobs are vital to the economy of any country, both now and in the future, and Brazil is no exception. With the high growth rates that Brazil has demonstrated in recent times, the need for quality professionals in STEM fields is increasing. However, few of Brazilian students are adequately prepared to fill these important and lucrative positions. Part of the problem in question is the lack of qualified teachers in many public schools in the country, who also have to follow a theoretical and, in many ways, uninspiring curriculum.

However, there have been taken some initiatives in order to fulfill the gap. Many organizations have been working on training Brazilian educators in Physics, Chemistry, Biology and Mathematics using new methodologies such as those based 
on projects. Participant teachers, when acting, inspire public school students to attend college and pursue careers in STEM.

A study carried out by the Federal Council of Engineering, Architecture and Agronomy; CONFEA found that Brazil would require at least 20 thousand new engineers per year to keep up with the fast development of the economy and the industrial sector. However, the same Council acknowledged that this would be a minimum, and a much higher number of graduated engineers would need to be trained in the years to come. The Brazilian government, through several programs enabled the number of graduated engineers to increase. Still, the percentage of graduated engineers related to the total number of graduates decreased during this period from $7 \%$ to $6 \%$, when in other countries such as China or South Korea, these figures are $35 \%$ and $25 \%$. Also, in comparative terms, Brazil graduates about 23 thous and engineers per year, when in South Korea this number is 80 thousand, India, 200 thous and, and in China, 400 thousand.

In this context, the associations linked to the Brazilian industry are concerned with the fact that, according to the federal government, the Brazilian youth in STEM and engineering programs is waning, underlining that only 120 thousand vacancies are filled from the 302 thousand available at engineering schools (at tertiary education level) [5].

As part of these efforts the Education Research Team of COPEC - Science and Education Research Council - has designed and implemented the K12 School Adventure Plan for a city, whose challenge is to provide better and effective knowledge for young students, even for those who will not enter University, with emphasis in STEM subjects.

\section{COPEC - Science and Education Research Council Research Team}

COPEC - Science and Education Research Council is a multi-disciplinary organization that is a leader in advance science and its application to the development of technology serving society. It started its activities sixteen years ago and since then this organization has made a major contribution to the development of science and education, working to increase the best practices in several research fields.

Integration activities promoted by COPEC provide a qualified coordination and building partnerships because COPEC is an organization that brings together scientists who share the mission of promoting and developing science, technology and education.

The objectives of COPEC are to promote professionalism, integrity, competency, and education; foster research, improve practice and encourage collaboration in the different fields of sciences.

Contents, tools and services provided by COPEC, through programs, publications and consultations with national and international experts, contribute to the promotion of the professional who wants to be privy of the new achievements and services of man on technology.

COPEC enjoys respect and recognition internationally, characterized by the open discussion, the free exchange of ideas, respectful debate and a commitment to 
rigorous inquiry. Its IIE - International Institute of Education - is a bold and resilient source of innovation in higher education [6][7][8].

\section{$7 \quad$ The Project}

Countries have been challenged to get development and keep up the economical growth, no matter the crisis that they eventually are passing. Brazilian government is investing in sciences and technology development and education is a big part of it. The Education Research Team of COPEC - Science and Education Research Council has designed and implemented a supplement K12 School program for a city, with the goal to provide better and effective knowledge for young students, especially those who will not enter a University. The chosen term 'Adventure' is because it is in fact an adventure through the sciences and technology world, by means of not only extra classes in science, technology, engineering, and math but also visits to interesting scientific and cultural sites.

The main goal is to help encourage more bright young minds to pursue careers in engineering and/or technology, by providing K12 students of public schools of a small city at the Atlantic Forest Region the necessary knowledge about sciences and research methodology which will remain as a life practice. It fits into the country's necessity to improve competitiveness in technology growth that has implications for the workforce development, as well as for science and technology development.

The program's main characteristic is the possibility to apply new and innovative approaches, which provide students the ability to develop concepts and theories to solve and understand scientific and nonscientific problems and, consequently, find solutions for those problems, too. It is a part-time program, delivered in two different mo ments during the day, in the morning and in the afternoon, always after the normal school period.

Students commute to the building that belongs to the City Hall, where they spend at least four hours having extra classes in the so called STEM - Science, Technology, Engineering and Mathematics fields with teachers especially hired to teach them. The program provides classrooms with multimedia resources and a class with computers for some activities, as well as visits to interesting sites are planned and delivered along the year. They also have visits to companies, museums, research centers, fairs, industries and other sites that can provide them a glimpse of a technological work atmosphere and the outcomes of these jobs.

Students are prepared to face the challenging process of university admission and even if they choose another path, or another career non-related with technology, or one that does not include university degree, they get the tools to face labor market too.

\section{Teachers}

Teachers are chemistry, computing, engineering and mathematics teachers (and/or university students) who volunteer to teach some hours per week in the program. Although they are volunteers, they get paid for their work, at least to cover transportation and food expenses. 
They are integrated also as part of the organization committee in order to settle the schedule in a six months period suggesting visits and works based on tasks that challenge the student's imagination and the willing to solve problems, to look for knowledge and take actions.

The contact with the real work world and the invitation to participate in talks help them to have an idea that they are equally capable to overcome the adversities and to pursue a career involving, preferably, sciences, mathematics and technology even if it does not involve a university degree.

The program also counts with the participation of emeritus professors, who also volunteer to teach and, furthermore, some take part in the board of directors.

TABLE I. SCHEDULE

\begin{tabular}{|l|l|c|}
\hline School classes & Morning & Afternoon \\
\hline \multicolumn{2}{|c|}{ Lunch time } \\
\hline Project classes & Afternoon & Afternoon \\
\hline
\end{tabular}

Because of time constrains, every activity has to be developed within a reasonable distance in $\mathrm{Km}$. This is why sometimes the best options are to invite lecturers to come to the students.

Every activity is scheduled on a time frame of 4 hours, not exceeding these hours, including visits and invited lectures.

It is framed and balanced so that students can have a dynamic and interesting week of activities, avoiding routine.

The activities start in March and ends in October, stopping in July and followed by the winter break. There are seven months of intense and pertinent knowledge classes. The activities follow an established organized schedule, in a way that both periods have visits on the same day or at least on the same week.

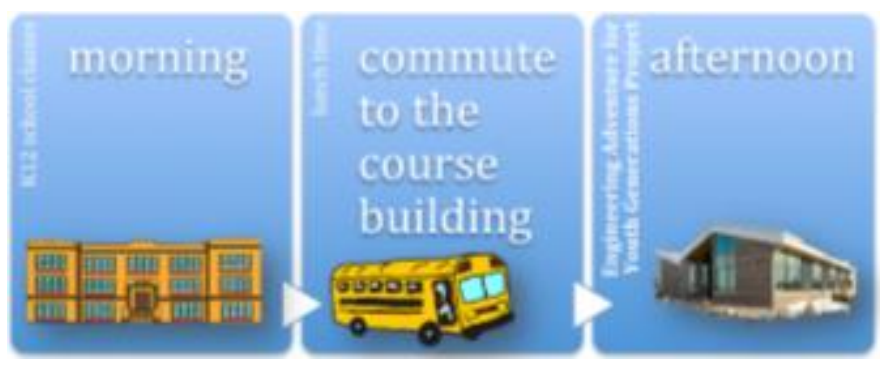

Fig. 3. Schedule.

\section{Some Details}

As mentioned above, classes are scheduled in the morning and in the afternoon, once schoolhours are in the morning and in the afternoon. 
The method starts with classes, which students have basic notions of scientific methodology in a language adapted to the students' age (as much as possible). STEM subjects, are combined with visits and lectures, which are followed by challenging problem-based classes to challenge the students to look for different ways to see and to solve problems.

Even the smallest detail of the classes are carefully examined and established, the disposal of the desks and the computer classes in different levels, besides the content in order to induce them to look at different options for their professional life, than what seems to be just arts, biology and letters.

Students have at their disposal a good equipped library, which was donated by some prominent people of the city, where students can go and look for extra information material.

There are always lecturers, even if they are only available for one period, another one will be invited to deliver the talk on the other period.

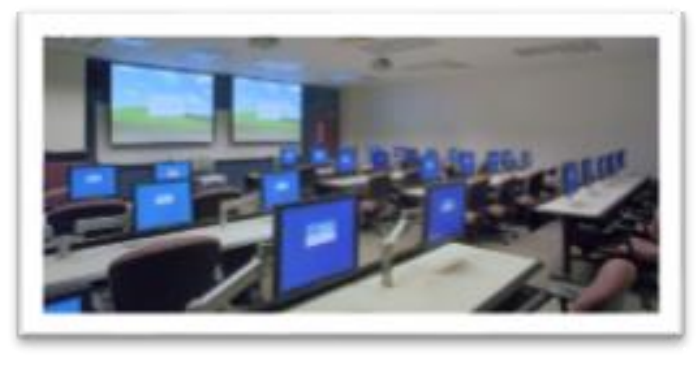

Fig. 4. Classroom.

The most important aspect is to provide the experience and contact with the professional and academic world, an immersion in scientific and cultural world in order to have a glimpse of the available opportunities.

The evaluation system is very s mooth, since they just self-evaluate their performances and knowledge acquisition, they update their own portfolio with the goal to give them the responsibility of their personal growth. This aspect seems to be very important once they can see the differences of thinking and viewing themselves and the possibilities that are open for them too.

\section{Conclusions}

The main objective of this program is primarily to prepare the young generation of a community to face the challenging process of university admission and even if they choose another path, one that does not include university degree, they get the tools to face the challenging mutant labor market too.

The program also provides new teachers the possibility to apply new and innovative approaches to motivate the students to develop concepts and theories to solve and understand scientific and nonscientific problems and to find appropriate solutions. 
The theoretical basis for this project is the Praxeology, the distinctive methodology of the earlier Austrian School of Economics, the liberal intellectual tradition of Ludwig von Mises (1881-1973) and Murray N. Rothbard (1926-1995) [7].

In 2014, university entry levels of public schools of the city have raised, what is a good sign that it is working and has contributed to the progress of $\mathrm{k} 12$ public school students' education continuity. However, it is not an indicator that the enrollment is specifically in STEM fields, once many of the chosen areas are still in human and biology sciences. Another aspect is that financial opportunities are bigger now, even with the economic crisis that the country is currently facing.

It is necessary one more year of activities in order to establish the real influence of the program in the enrollment of students in sciences and technology university programs.

\section{Acknowledgment}

This work has been financed by FEDER funds through the Competitivity Factors Operational Programme - COMPETE: POCI-01-0145-FEDER-007136 and POCI-010145-FEDER-007043 and FCT - Fundação para a Ciência e Tecnologia within the Project Scope: UID/CEC/00319/2013.

\section{References}

1. Hom, Elaine J. (2014). LiveScience Contributor in a article of February 11, 2014. What is STEM Education-LiveS cience

2. OECD. (2011). "Share of formal employment continues to grow". G20 Country Policy Briefs-Brazil. Paris: OECD.

3. Oliveira, V. F. (2005). "Crescimento, evolução e o futuro dos cursos de engenharia". Revista de Ensino de Engenharia, 24 (2), 3-12.

4. Gadotti, Moacir. "Perspectivas atuais da educação". São Paulo em perspectiva,14.2 (2000): 03-11.

5. IPEA (2009). "Emprego - Profissões em alta- Crescimento vai aumentar demanda de engenheiros e técnicos". Desafios do desenvolvimento, 7 (55) (available at http://goo.gl/3if1TX)

6. Brito, C. da R., Ciampi, M. M., Vasconcelos, R. M. C. F., Amaral, L. A. M., and Barros, V. F. A. (2016). "Engineering Adventure for Youth Generations," in 2016 ASEE Annual Conference, New Orleans, Louisiana: ASEE (available at https://peer.asee.org/26608).

7. Brito, C. da R., Ciampi, M. M., Amaral, L. A., Vasconcelos, R. M., and Barros, V. F. de A. (2015). "K12 Enhancement Program: Engineering the Future of an Entire Young Population," in SEFI Annual Conference 2015, Orléans, France: SEFI (available at http://www.sefi.be/conference-2015/CHAP 16.).

8. Brito, C. da R.; Ciampi, M. M.; Vasconcelos, R. M. C. F.; Amaral, L. A. M.; Barros, V. F. A. (2014). "Innovative on Demand International Engineering Programs" in European Society of Engineering Education Annual Conference, 42, Birmingham, 2014. Educating Engineers for Global Competitiveness. Birmingham: SEFI, 2014. 